\title{
Primary Eustachian Tube Tuberculosis
}

\section{Birincil Östaki Tüpü Tüberkülozu}

\section{Mohd Hafiz HAMZAH $\odot$, Irfan MOHAMAD $\odot$, Nor Shahida Abd MUTALIB $\odot$}

Ethics Committee Approval: Not Applicable.

Conflict of Interest: The authors declare that they have no conflict of interest.

Funding: None.

Informed Consent: Inform consent was taken.
Cite as: Hamzah $\mathrm{MH}$, Mohamad I, Mutalib NSA. Primary eustachian tube tuberculosis. Medeni Med J. 2021;36:172-5.

\begin{abstract}
Nasopharyngeal tuberculosis is a rare occurrence, and primarily involves the proximal part of the Eustachian tube. Mechanical obstruction of the Eustachian tube will affect the pressure discrepancy between the middle ear and the external atmosphere, leading to aural fullness, unilateral hearing disturbance, and otitis media. These conditions can be overlooked or mistakenly diagnosed as ear pathology. We report a case of unilateral hearing loss and tinnitus in a 31-year-old healthy woman that was later confirmed to be tuberculosis of the Eustachian tube. In cases with indicators suggesting a high index of suspicion, a thorough examination of the head and neck regions is especially very important. Once it has been diagnosed, Eustachian tuberculosis can be successfully treated with anti-tuberculosis medications.
\end{abstract}

Keywords: Eustachian tube, tuberculosis, unilateral hearing loss

öz

Nazofarengeal tüberküloz, östaki borusunun proksimal kısmının tutulumu başta olmak üzere nadir bir durumdur. Östaki borusunun mekanik açıdan tıkanması, orta kulak ile dış atmosfer arasındaki basınç uyumsuzluğunu etkileyerek işitsel dolgunluğa, tek taraflı işitme bozukluğuna ve orta kulak iltihabına yol açacaktır. Bu durumlar gözden kaçabilir veya yanlıșlıkla kulak patolojisi gibi teşhis edilebilir. Otuz bir yaşında olan sağlıkı bir kadında daha sonra östaki borusu tüberkülozu olduğu doğrulanan tek taraflı işitme kaybı ve kulak çınlaması vakası sunuyoruz. Şüpheli gösterge indeksinin yüksek olduğu durumlarda, baş ve boyun bölgesinin derinlemesine incelenmesi özellikle çok önemlidir. Teşhis konulduğunda östaki tüberkülozu, anti-tüberküloz ilaçları ile başarılı bir şekilde tedavi edilebilir.

Anahtar kelimeler: Östaki borusu, tüberküloz, tek taraflı işitme kaybı
Received: 22 December 2020 Accepted: 30 March 2021 Online First: 18 June 2021

\section{Corresponding Author:}

I. Mohamad

ORCID: 0000-0001-8572-0514

Universiti Sains Malaysia, Health Campus, School of Medical Sciences, Department of OtorhinolaryngologyHead \& Neck Surgery, Kota Bharu, Kelantan, Malaysia

irfankb@usm.my

M.H. Hamzah ORCID: 0000-0002-7488-3104

Universiti Sains Malaysia, Health Campus, School of Medical Sciences, Department of OtorhinolaryngologyHead \& Neck Surgery, Kota Bharu, Kelantan, Malaysia

N.S. Abd Mutalib ORCID: 0000-0003-3297-497X

Hospital Sultan Abdul Halim, Department of OtorhinolaryngologyHead \& Neck Surgery, Sungai Petani, Kedah, Malaysia 


\section{INTRODUCTION}

Head and neck involvement in tuberculosis (TB) is rare, comprising only $10 \%$ of extrapulmonary tuberculosis. Eustachian-tube TB is an extremely rare disease even in areas where TB is endemic. Only one case of primary Eustachian-tube TB has been reported since 2010 until now in Pubmed. The symptoms vary and may manifest either as otologic or rhinologic symptoms or both.

\section{CASE REPORT}

A 31-year-old healthy woman presented with complaint of reduced hearing in her left ear for four months which was associated with tinnitus in her left ear. There was no ear pain, discharge, or fever. She denied any nasal symptoms, chronic cough, or weight loss, and any previous contact with TB patients. She was previously treated for otitis media with multiple courses of oral antibiotics prescribed by a general practitioner, but the symptoms persisted.

Clinically, she was well. Otoscopy showed a normal external auditory canal with dull left tympanic membrane. The right ear was normal.

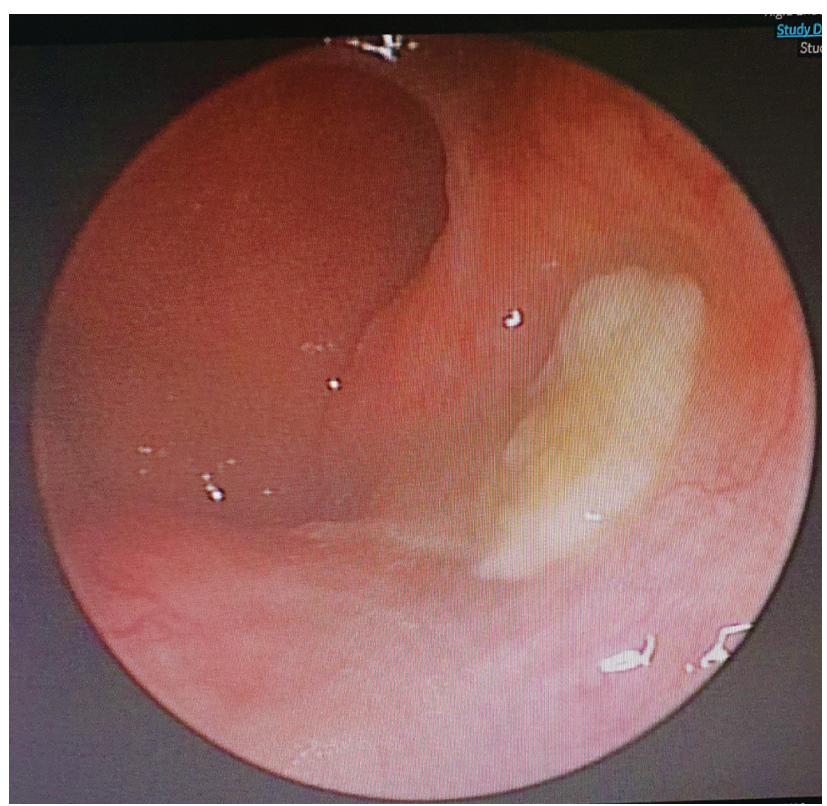

Figure 1. Nasal endoscopy showed slough covering Eustachian tube orifice.
Nasoendoscopy revealed yellowish slough covering the left Eustachian tube opening (Figure 1). The slough was biopsied and the specimen was sent for histopathological examination (HPE) and acid-fast bacilli (AFB) staining. No cervical lymph node was palpable. Tympanometry showed type B tympanogram pattern in the left and type A tympanogram pattern in the right ear. Pure tone audiometry (PTA) was consistent with moderate mixed hearing loss in her left ear.

Chest radiograph was normal. The staining for AFB was positive and the HPE of the slough was reported as nonspecific inflammation. An earlymorning sputum test for AFB performed for three consecutive days and Mycobacterium tuberculosis culture were negative.

She was diagnosed with nasopharyngeal TB. The intensive phase anti-TB treatment consisting of isoniazid, rifampicin, pyrazinamide, and ethambutol was started for 84 doses followed by a maintenance treatment with rifampicin and isoniazid for 120 doses. Nasal endoscopy showed a complete resolution of slough near the Eustachian tube opening after three months of treatment (Figure 2). Repeated PTA showed normal hearing

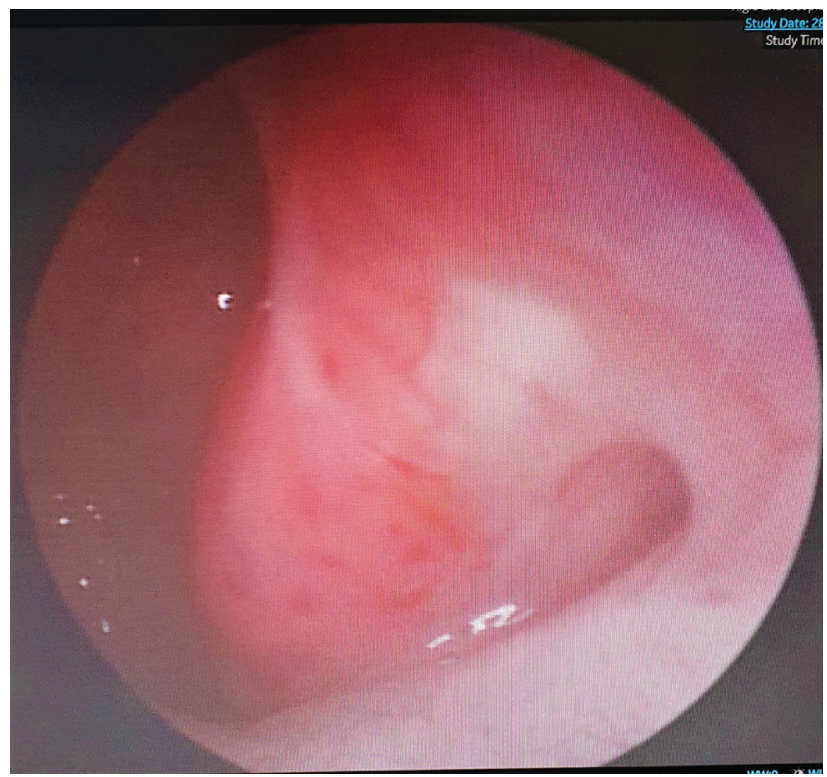

Figure 2. Complete resolution of slough at Eustachian tube orifice. 
in both ears and tympanometry type A tympanogram in both sides. Subsequently she completed six months of anti-TB therapy.

A follow-up for one year after the completion of the anti-TB treatment showed no ear or nasal symptoms. A nasal endoscopy revealed normal nasopharynx and Eustachian tube. Her hearing was also normalised.

\section{DISCUSSION}

Tuberculosis (TB) is a highly communicable disease caused by Mycobacterium tuberculosis. Up to $10 \%$ of extrapulmonary TB involves the head and neck regions, with cervical lymph nodes being most frequently involved ${ }^{1}$. Eustachian-tube TB is a very rare case even across areas of the world where TB is endemic ${ }^{2,3}$.

This patient did not show any symptoms of pulmonary TB such as chronic cough, night fever, night sweats, or loss of weight. The Eustachian tube as the primary TB pathogenesis can be attributed to the nasopharyngeal TB. Reactivation of dormant Mycobacterium tuberculosis in the adenoid or inhalation of the bacteria can lead to primary nasopharyngeal $\mathrm{TB}^{4}$.

Primary Eustachian-tube TB has been reported to present with aural fullness and hearing disturbance in a patient with a previous history of pulmonary $\mathrm{TB}^{5}$. These patients may have systemic symptoms such as malaise, night fever, and sweat as well. In our case, a healthy woman presented with reduced unilateral hearing and tinnitus in her left ear. Stress and a period of infection causing the patient to have a temporarily low immune status may lead to reactivation of dormant Mycobacterium tuberculosis. Both symptoms of tinnitus and reduced hearing can be explained by the mechanical obstruction of the Eustachian tube. Middle-ear TB, which is more commonly reported, may also demonstrate the same symptoms as Eustachian-tube TB. However, there are classical triad of the symptoms of painless otorrhea, multiple perforations of the tympanic membrane, and facial nerve palsy in the middle-ear TB.

Yellowish slough on the Eustachian tube orifice can be easily mistaken for purulent discharge in rhinosinusitis. In that case, if the obtained sample is sent for swab culture and sensitivity rather than Ziehl-Neelsen staining, then diagnosis and also treatment will be delayed. In our case, rhinosinusitis was unlikely due to the history of non-resolving symptoms with multiple courses of antibiotics, which makes the infection less likely to be bacterial in origin. Other possible differential diagnoses are fungal rhinosinusitis and nasopharyngeal carcinoma.

Detailed history-taking and a thorough endoscopic and radiological examinations are very important to avoid misdiagnosis, as the clinical presentations vary. The gold standard investigation for TB is to send sputum or tissue sample for Mycobacterium spp. culture. However, due to the time-consuming nature of the test, which takes four to six weeks to yield results; ZiehlNeelsen staining for AFB is highly reliable, faster, and less costly compared to bacterial cultures or TB polymerase chain reaction $(\mathrm{PCR})^{6}$. Once the diagnosis of Eustachian-tube TB is confirmed, the disease can be successfully treated with anti-TB medications within a minimum duration of six months ${ }^{2}$.

\section{CONCLUSION}

Primary Eustachian-tube TB is a rare disease but treatable. In a patient with unilateral hearing loss, the nasopharynx needs to be examined for the presence of adenoid hypertrophy, an antrochoanal polyp, or nasopharyngeal carcinoma. TB also needs to be excluded due to a rising number of cases reported. Although the symptoms vary, a simple nasoendoscopic examination can reveal the findings. A simple yet reliable test such as AFB may confirm the diagnosis, thus avoiding 
potential complications such as scarring of the Eustachian tube opening that leads to recurrent otitis media or a spread of the TB into the middle ear.

\section{REFERENCE}

1. Menon K, Bem C, Gouldesbrough D, Strachan DR. A clinical review of 128 cases of head and neck tuberculosis presenting over a 10-year period in Bradford, UK. J Laryngol Otol. 2007;121:362-8. [CrossRef]

2. Srirompotong S, Yimtae K, Jintakanon D. Nasopharyngeal tuberculosis: manifestations between 1991 and 2000.
Otolaryngol Head Neck Surg. 2004;131:762-4. [CrossRef]

3. Chow TK, Loh ZH, Sinnathamby PA. A case of nasopharyngeal tuberculosis. Asian Journal of Research in Surgery. 2019;2:1-4. [CrossRef]

4. Sithinamsuwan P, Sakulsaengprapha A, Chinvarun Y. Nasopharyngeal tuberculosis: a case report presenting with diplopia. J Med Assoc Thai. 2005;88:1442-6. PMID: 16519394.

5. Oh SJ, Yi KI, Lee CH, Cho KS. Primary tuberculosis of the eustachian tube causing otitis media with effusion. Am J Otolaryngol. 2015;36:575-7. [CrossRef]

6. Srivanitchapoom C, Sittitrai P. Nasopharyngeal tuberculosis: epidemiology, mechanism of infection, clinical manifestations, and management. Int J Otolaryngol. 2016;2016:4817429. [CrossRef] 